\title{
Human Suffering in Need of God's 'Face' and 'Eyes': Perspectives on Psalm 13
}

\author{
Dirk Human (University of Pretoria)
}

\begin{abstract}
The COVID-19 global pandemic and its consequent outcomes have caused immense suffering and distress in every community and at all levels of life worldwide. Theological and religious communities raise the question about God's involvement in the causes of and healing from this horrendous misery and grief. These questions become paradigmatic of how God is involved in suffering and how the supplicant could experience deliverance through interaction with God, whilst situated in the midst of such a crisis.

Exegetic contemplation on $P s$ 13, a well-known lament song, provides an exemplary experience of a psalmist in a severe lifeendangering context. An exposition of the text-its historical, cultic and literary contexts - and the genre of 'lament' brings insight into the Yahweh-believer's interaction. Without pretending to provide answers to enigmatic forms of suffering, this article shows how Yahweh-believers in ancient Israel understood and reacted to suffering. Human suffering is indeed in need of the 'face' and 'eyes' of Yahweh to experience healing and redemption.
\end{abstract}

KEYWORDS: Psalm 13, Psalms 1-14, lament, suffering and affliction, COVID-19, SDGs

\section{A INTRODUCTION}

Human suffering has shown various faces in the 20th and 21st centuries, with a special ugly face of a global pandemic in 2021. Despite the two World Wars (1914-1918; 1939-1945), the Cold War (1947-1991), severe droughts, Spanish flu (1918), pandemics caused by the Ebola and HIV/AIDS viruses, a nuclear accident at Chernobyl on 26 April 1986, regional wars in the Middle and Far

* Submitted: 17/02/2021; peer-reviewed: 14/04/2021; accepted: 05/05/2021. Dirk Human, "Human Suffering in need of God's 'Face' and 'Eyes," Old Testament Essays 34 no. 1 (2021): 268 - 284. DOI: https://doi.org/10.17159/23123621/2021/v34n1a15.

I attribute this article in gratitude to a colleague and friend, Prof S. (Fanie) D. Snyman, who was an esteemed and valued discussion partner in Old Testament Studies for many years. The article and theme of 'suffering' relates to the UN Sustainable Development Goals (SDG’s) 1-6, 10, 15, 16. 
East and massacres such as in Rwanda (7 Apr - 15 Jul 1994) or famine and poverty in Africa and elsewhere, no suffering in the modern world compares with the outbreak of the COVID-19 global pandemic and its severe consequences in $2020 .^{1}$

The COVID-19 global pandemic has plunged the world into severe suffering. Alongside the suffering caused by the global ecological and climate change, ${ }^{2}$ this ugly pandemic is the reason that millions of people are sick and millions are dead. Furthermore, this virus and the consequent lockdowns worldwide have led to economic, ${ }^{3}$ social, political ${ }^{4}$ and religious turbulence. Globally and in the South African context, this situation has been accompanied by increase in social ills such as state corruption, ${ }^{5}$ killings, domestic violence, ${ }^{6}$ women abuse, racism ${ }^{7}$ and many more. In many respects, people's lives have been touched by death, destruction and a lack of meaning.

The above state of affairs also has left religious communities and individuals with many faith questions: where is God amidst all this suffering? Why is God silent? How can I/we find healing from my/our pain and suffering? Is restoration of life possible after such severe affliction and devastation? Is there still hope beyond the suffering of COVID-19 and other life-threatening afflictions?

1 See, for statistics and other information on COVID-19, Online: https://www.google.com/search?q=covid+19. Accessed on 20 March 2021.

2 Phikalu Panu, "Anxiety and the Ecological Crisis: An Analysis of Eco-Anxiety and Climate Anxiety," Sustainability 12/19 (2020): 7836, 1-20.

3 See Warwick McKibbin and Rochen Fernando, "The Economic Impact of COVID-19" in Economics in the Time of COVID-19 (ed. Richard Baldwin and Beatrice Weder di Maur; London: CEPR Press, 2020), 45-51.

4 See online: https://www.russellsage.org/research/funding/covid-19-pandemic for the social, political, economic and psychological impact of the COVID-19 pandemic, Accessed on 20 March 2021.

5 See Jacobus M. Vorster, "Managing Corruption in South Africa: The Ethical Responsibility of Churches," Scriptura 109 (2012): 133-147; Ferdinand Kruger and Ben de Klerk, Corruption in South Africa's Liberal Democratic Context: Equipping Christian Leaders and Communities for Their Role in Countering Corruption (Cape Town: AOSIS, 2016); Muhammad Salahuddin, Nick Vink, Nicholas Ralph and Jeff Gow, "Globalisation, Poverty and Corruption: Retarding Progress in South Africa," Development Southern Africa 37 (2020): 617-643.

6 See Princilla Daniels and Tracy-Ann Adonis, "Domestic Violence in South Africa: Problems and Prospects," in Global Responses to Domestic Violence (ed. E.S. Buzawa and C.G. Buzawa; New York: Springer Publishing, 2017), 151-164.

See Sharelle Barber, "Death by Racism.” The Lancet (Aug 20 2020): 903. 
Every human being traverses the space between life and death - a journey that is shorter for some and longer for others. People's passage through life occasionally brings them very close to the pole of death and regularly brings tension to the experience of their existence - a tension that has been articulated in numerous ways by countless poets and across many generations. In times when death threatens to engulf the believer, he/she typically seeks the saving intervention of God - an expectation that often leads, within the Psalms and other protest literature, to tension that finds expression in a discourse of protest against and conflict with God. ${ }^{8}$

A theological contemplation of the lament in Ps 13 displays a paradigmatic experience of a psalmist in severe life-endangering distress. An exposition of this text, its historical, cultic and literary contexts and the genre of 'lament' brings insight into the Yahweh-believer's interaction with God. Without pretending to provide answers to various forms of suffering, this article aims to portray how Yahweh-believers in ancient Israel understood and responded to human suffering. The psalm indeed confirms that human suffering is in need of the 'face' and 'eyes' of Yahweh to experience healing and meaning in life.

\section{B PSALM 13 - A LAMENT DISPLAYING CONFLICT, PRAYER, TRUST AND PRAISE}

\section{Introduction}

Psalm 13 gives expression to a believer's experience that God has deserted him or her in the face of the abyss of death. The perceived absence of God and the threat of the enemy brings the afflicted psalmist to cry out for help in the hopelessness of his misery, "How long, o Lord, how long, how long, how long?" (Ps 13:2-3). These words begin a wrestling with God that is arguably the most concise articulation of a crisis experience in the Old Testament.

Not only is this psalm a prototype of the literary genre "lament of the individual," move in their wrestling from lamentation to praise-a pattern that occurs often in the structure of the so-called psalms of lamentation ${ }^{10}$ and in the Psalter as a

8 I borrow this concept of discourse of conflict from Janowski, who describes the theological anthropology of the Psalms in Bernd Janowski, Konfliktgespräche mit Gott: Eine Anthropologie der Psalmen (Neukirchen: Neukirchener Verlag, 2013).

9 Hermann Gunkel, Die Psalmen (4th ed.; HAT 2/2; Göttingen: Vandenhoeck \& Ruprecht, 1926), 46.

10 Erhard S. Gerstenberger, Psalms Part 1. With an Introduction to Cultic Poetry (FOTL 14; Grand Rapids: Eerdmans, 1988), 10-14. 
whole. ${ }^{11}$ Furthermore, the psalm functions as a paradigm for a discourse of conflict with God, which characterises the theological anthropology of the Psalms. ${ }^{12}$

The theology of the psalm offers the contemporary reader a valuable dialogue partner in making sense of the absence of God and the threat of death, particularly when God is perceived as "silent" and "inactive," when the imminence of death and the hostility of enemies grows ever stronger. The believer perceives that God turns his 'face' away and does not listen to the supplicant's distress.

While the psalm poses few problems of interpretation, ${ }^{13}$ some aspects occupy exegetes' exegetical imagination. In addition to the obvious theological significance of the psalm in the theodicy debate, other challenges of interpretation include (1) v. 3b ("spend every day with concern in my heart") as a possible later addition to the psalm, ${ }^{14}$ (2) the interpretation of the time perspectives in v. 6 and (3) the redactional position of Ps 13 in the smaller group of Pss 3-14 (Pss 11-14) ${ }^{15}$ and as part of the first collection of Psalms of David (Pss 3-41).

\section{Text and translation}

The Hebrew text of Ps 13 is well preserved. Therefore, the psalm requires no text-critical amendments in order to construct a comprehensible text. The metre of the verse lines is irregular but it displays a pattern that results in a staircase build-up of the poem. This build-up, in turn, displays a poetical structure that

11 Bernd Janowski, "Ein Tempel aus Worten: Zur theologischen Architektur des Psalters," in The Composition of the Book of Psalms (ed. Erich Zenger; BETL; Leuven: Peeters, 2010), 279-306 (290).

12 Friedhelm Hartenstein, “'Schaffe mir Recht, JHwH' (Psalm 7,9): Zum theologischen und antropologischen Profil der Teilkomposition Psalm 3-14," in The Composition of the Book of Psalms (ed. Erich Zenger; BETL; Leuven: Peeters, 2010), 229-258 (252).

13 Willem S. Prinsloo, Die Lof van my God Solank Ek Lewe (Centurion: Medpharm, 2000), 44.

14 Zenger argues that the verse line may have been added by an "exilische Armenredaktion" that compiled the group of Pss 11-14. See Erich Zenger, "Psalm 13," in Psalmen 1-50 (Part 1 of Die Psalmen; ed. Erich Zenger and Frank-Lothar Hossfeld; NEchtB; Würzburg: Echter Verlag, 1993), 96.

15 See Erich Zenger, "Einführung," in The Composition of the Book of Psalms (ed. Erich Zenger; BETL; Leuven: Peeters, 2010), 1-14 (9-10); Hartenstein, "Schaffe mir Recht, Jнwн," 251-252. 
consists of "three ascending themes and three descending themes"16 that can correctly be described as a ziggurat with three liturgical "steps" namely lament-prayer-praise. ${ }^{17}$ The Hebrew text with a possible translation reads as follows:

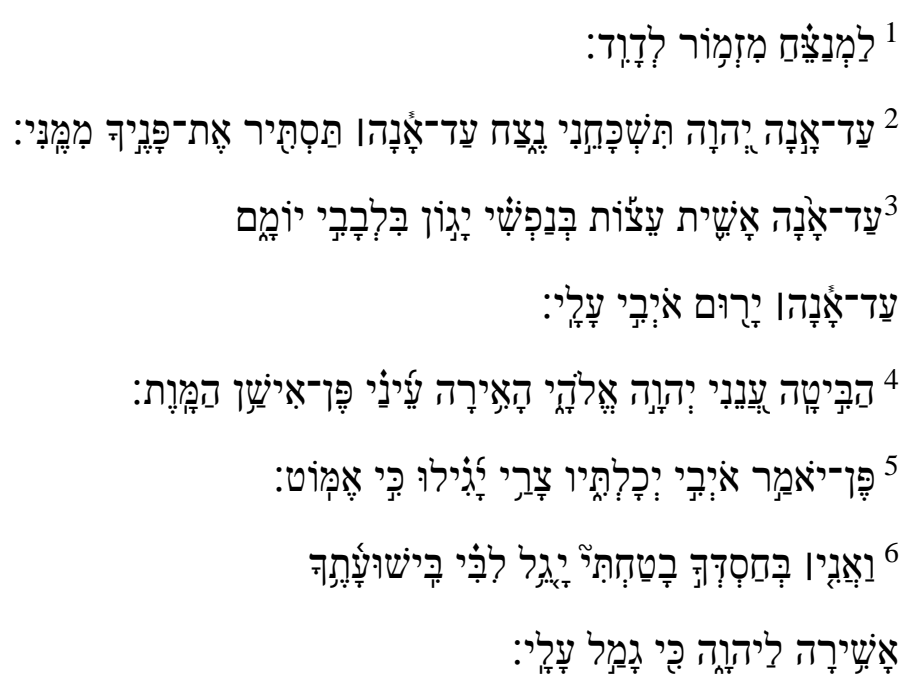

1 To the music leader. A Psalm. Of David.

2 How long, O LORD? Will you forget me forever?

How long will you keep hiding your face from me?

3 How long must I carry sorrow in my being, and spend every day with concern in my heart?

How long will my enemy exalt himself over me?

$4 \quad$ Look at me and answer me, o LORD, my God!

of death;

Keep the light in my eyes, so that I do not sink away in the sleep

5 so that my enemy may not say, "I have overcome him," and my adversaries not rejoice because I stumble.

6 But as for me - I trust in your steadfast love;

16 Terrien identified this chiasm of themes with v. 4 as the centre: "so that I don't sink away in the sleep of death." See Samuel Terrien, The Psalms: Strophic Structure and Theological Commentary (Grand Rapids: Eerdmans, 2003), 158-159.

17 Gerstenberger, Psalm 1, 85. 
my heart rejoices in your salvation.

I will sing to the LORD, because He has done good to me!

The Hebrew text displays proprietary syntactic and stylistic features. ${ }^{18}$ Some of the most significant stylistic features include (1) the prevalence of the rhetorical question [vv. 2-3]; (2) repetition [vv. 2-3, 4-5]; (3) word play [vv. 4, 5]; sound play [e.g. the alliteration of $m$ and $n$ sounds]; (4) parallelism [vv. 2, 3]; (5) chiasm [v. 6]; and (6) contrast [lament and praise; suppression and salvation]. Interaction in the text takes place between the three most important actors namely God, "I" and the enemy - a triangular relationship that characterises many psalms and develops the potential of conflict between the different parties. The name of God (YAHWEH) appears in each stanza (vv. 2, 4, 6) and functions as a significant marker of structure in the text.

The notion and roles of God (1-3), the "I" (3-6) and the enemy (4) is significant in the structure of the complaint (2-3). Although there is no narrative or elaborate description of suffering in the psalm, these actors denote the spheres from where human misery and suffering come. Life-endangering distress and affliction are caused by God, by the self and by external hostile forces. ${ }^{19}$ The complaint/lament therefore has a theological, a personal and a social element. ${ }^{20}$ Relationship and interaction between these actors display the suffering and deliverance scenarios in Ps $13 .{ }^{21}$

\section{$3 \quad$ Genre and structure}

While it remains a preliminary categorisation, the genre description of "lament of the individual" is best suited to our text. ${ }^{22}$ Indeed, Ps 13 serves as a classic

18 For a complete analysis of these syntactic and stylistic features and how they impact the interpretation of the psalm, see Prinsloo, Lof van my God, 45-47, 49-51.

19 Cf. Hans-Winfried Jüngling, "Psalms 1-41" in International Bible Commentary (ed. William R. Farmer; Collegeville: Liturgical Press, 1998), 790-791; Janowski, Konfliktgespräche, 57-60.

20 Cf. Rolf Jacobson, "Psalm 13: Waiting on the Lord," in The Book of Psalms (ed. Nancy DeClaissé-Walford, Rolf A. Jacobson and Beth L. Tanner NICOT; Grand Rapids: Eerdmans, 2014), 158-163 (159).

21 Cf. Bernd Janowski, Anthropologie des Alten Testaments: Grundfragen Kontexte - Themenfelder (Tübingen: Mohr Siebeck, 2019), 272, 483.

22 In the footsteps of Hermann Gunkel, see Gerstenberger, Psalms 1, 10-14, who provides a complete breakdown of the elements that appear in the lament. Not all elements appear in every psalm of this genre category. See also Klaus Seybold, Die Psalmen (HAT I/15; Tübingen: Mohr (Siebeck), 1996), 64; Willem Prinsloo, 
example and prototype of this genre ${ }^{23}$ with the following elements of the category appearing in the psalm: (1) the call to God [vv. 2, 4], (2) lament or description of the need of the prayer [vv. 2-3]; (3) prayer requests [vv. 4-5]; (4) declaration of trust [v. 6a] and (5) a promise of praise as thanksgiving [v. 6b].

Typologies of the psalm as a hymn of prayer, ${ }^{24}$ a prayer, ${ }^{25}$ a communal lament ${ }^{26}$ or even a kingship psalm in the context of a rite of lament ${ }^{27}$ do not convince fully, since these descriptions only refer to aspects of the psalmist's experience. There is no explicit reason to understand the "I" of the psalm as referring to either a collective or an individual (e.g. the king). Upon later reading of the psalm - from a redactional perspective (as part of the group of Pss 3-14), however, it does become possible to interpret the "I" as Israel's (exilic/post-exilic) experience of suppression and salvation (cf. Ps 14:7). However, on the level of the single psalm this might be interpreted differently. Thus, both individual and collective interpretations are valid and possible readings of the psalm on different levels.

Formal similarities and parallels with Near Eastern laments are striking (e.g. "How long?"). ${ }^{28}$ Comparisons of literary expressions and semantic descriptions from the Hebrew lament with Babylonian (Akkadian and Sumerian) literature and poetry indicate similar ideas about the role of the

Eerdmans Commentary on the Bible (ed. James D.G. Dunn and John W. Rogerson; Grand Rapids: Eerdmans, 2003), 366-373 (367).

23 The vast majority of exegetes accept this genre description of the psalm as a lament of the individual. See, for example, Gunkel, Psalmen, 46; Jean P.M. van der Ploeg, Psalmen (Roermond: Romen en Zonen, 1971), 92; Arnold A. Anderson, Psalm 1-72 (vol. 1 of The Book of Psalms; NCBC; Grand Rapids: Eerdmans, 1972), 128; Gerstenberger, Psalms 1, 85; Claus Westermann, The Living Psalms (trans. J. R. Porter; Edinburgh: T \& T Clark, 1989), 68; Zenger, Psalmen 1, 96; Klaus Seybold, Die Psalmen (HAT I/15; Tübingen: Mohr Siebeck, 1996), 64; Prinsloo, Lof van my God, 46; Richard J. Clifford, Psalms 73-150 (AOTC; Nashville: Abingdon, 2003), 85; Hartenstein, "Schaffe mir Recht, JHWH," 252; etcetera.

24 Hans-Joachim Kraus, Psalmen (BKAT 15/1; Neukirchen: Neukirchener Verlag,1978), 240.

25 See James Mays, Interpretation: Psalms (Louisville: John Knox, 1994), 77, who describes the psalm as "the shortest of the prayers for help in the Psalter." See also Terrien, Psalms, 158.

26 Sigmund Mowinckel, The Psalms in Israel's Worship (vol. 1; Oxford: Blackwell, 1967), 219, 229.

27 Aage Bentzen, King and Messiah (Oxford: Blackwell, 1955), 25.

28 The question 'how long?" is a characteristic feature in both collective and individual lament psalms (see Pss 6:3; 74:10; 795; 80:4; 90:13; 94:3). The repetition of the question has the function to intensify the crisis and also introduces variety. See Jacobson, Book of Psalms, 160. 
lament in the ancient Near East. ${ }^{29}$ Hebrew poets incorporated ancient Near Eastern language and motifs in their religious literature and applied them to Yahwism, resulting in its differences from Mesopotamian prayers and laments.

The syntactic and stylistic features of Ps 13, along with the elements of its genre, suggest the following structure for the psalm:
$1 \quad$ Heading
2-3 Lament to Yahweh
4-5 Prayer for salvation
6a Declaration of trust
6b Promise of praise as expression of gratitude

\section{Text analysis}

The psalm begins with a complaint (vv. 2-3). Four times the psalmist calls on the LORD, Yahweh, with the rhetorical question, "How long, o LORD?"30 emphasising his anxiety and the seriousness of his dire situation. The prayer does not hold back but instead confronts the Lord in an honest-to-God conflict address, demonstrating the enduring nature of his misery with the time indicators "always" (v. 2) and "every day" (v. 3).

The fact that the psalmist turns to God in his moment of distress illustrates, on the one hand, his trust that the Lord can come to his rescue, while hinting at his impatience and even resentment that God has left him in his misery for so long, on the other hand. For this reason, then, his fourfold complaint places the roles of God, the prayer and the latter's enemy in equal perspective. God is held responsible for the anguish of the psalmist, having

29 An example in this regard is the lament to the goddess Ishtar, see Hugo Gressmann et al., Altorientalische Texte zum alten Testament (Berlin/Leipzig: Walter de Gruyter, 1926), 257-260. See also Van der Ploeg, Psalmen, 93; Kraus, Psalmen, 241; Gerstenberger, Psalms 1, 84, for the significance of similarities and differences in these types of literature. William Hallo and K.L. Younger, The Context of Scripture: Canonical Compositions from the Biblical World. (Vol.1; Leiden: Brill, 1997), 419-420, 535-539. The lamentation to Ishtar (lines 93-96) reads:

How long, O my Lady, wilt thou be angered so that thy face is turned away?

How long, $\mathrm{O}$ my Lady, wilt thou be infuriated so that thy spirit is enraged?

Turn thy neck which thou hast set against me; set thy face [toward] good favour.

See James Pritchard, Ancient Near Eastern Texts Relating to the Old Testament (Princeton: Princeton University Press, 1969), 385.

30 The question emphasises the unbearable nature of the distress and appears often in the Psalms (e.g. Pss 6:4; 35:17; 74:10; 79:5; 94:3; 80:5). 
perpetually "forgotten" him and having "hidden" his face from him. ${ }^{31}$ In this way, the prayer's distress is sketched in such a way as to portray him as someone forsaken by his God. His communion with God has been cut off so that God does not offer his favour or salvation to the helpless believer but holds back his life-giving power. God is hiding his face from the supplicant.

Being forsaken by God holds both internal and external consequences for the complainant. He suffers physically, psychologically and socially, ${ }^{32}$ carrying sorrow and concern in his deepest being (v. 3a). He spends his days in worry and distress (v. 3b) and has to reckon with the actions of his enemy. The manner in which this enemy exalts himself over the complainant may indicate arrogance, suppression or both. Whatever the case may be, the complaint makes it clear that, over and above being forsaken by God, the supplicant carries inner tension brought about by concerns and anxiety, all the while fearing his enemy.

With three imperatives, followed by three sentences expressing negative purpose, the psalmist prays to Yahweh, his God (vv. 4-5). His address of God as "my God" bears witness to a personal relationship between God and the psalmist. His three requests - that God will "behold/look at" him (v. 4),

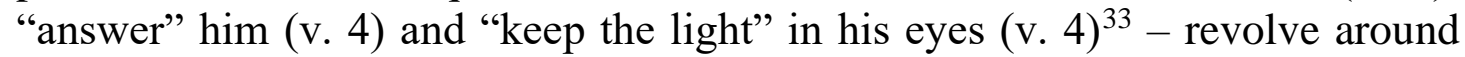
the senses of "seeing" and "hearing." 34 At the same time, the fact that God is requested to "look" 35 hints at distance between God and the supplicant. Yahweh's glance- - his eyes - are needed to bridge this abyss of God's absent healing power. All three requests aim to convince God to strengthen the psalmist, who feels deserted by God and is wrought with anxiety of death, with new vitality.

31 Both the concepts of "forgetting" and "hiding the countenance" appear in Ps 10:1, 11. That God "hides his face" hints at the rituals surrounding a royal audience. When a subject makes a request to the king during an audience and the king turns his face away, it indicates that the king has withdrawn his favour such that it could even result in the death of the subject. See Friedhelm Hartenstein, Das Angesicht JHWHs (FAT 55; Tübingen: Mohr, Siebeck, 2008), 65-205. This expression appears often both within and outside the Psalms (Hartenstein, Das Angesicht, 244-254). Cf. also Deut 32:20; Job 13:24; Pss 44:24; 88:14, etcetera.

32 Clifford, Psalms 73-150, 86.

33 In the ancient world, the eye functioned as an instrument whereby pain, disease, fatigue, age and concerns could be measured. See Anderson, Psalms 1-72, 129; Georg Fohrer, Psalmen (Berlin/New York: Walter de Gruyter, 1993), 147. cf. Deut 34:7; Job 17:7; 1 Sam 14:27; Pss 6:8; 38:11; Lam 5:17. An eye that receives light anew indicates that vitality, health and fortitude have been restored.

34 "Seeing," "hearing" and "remembering" "are not states of consciousness, but preludes to God's action" (Exod 2:24-25); cf. Derek Kidner, Psalms 1-72 (Tyndale Old Testament Commentaries; London: Intervarsity Press, 1973), 77.

35 See Pss 33:13; 80:15; 102:20; 104:32; 113:5-6. 
The psalmist fears that, should God not act, he will be permanently cut off from the LORD through death. ${ }^{36}$ His enemies will think that they have overcome him. The double allusion of the verse line (v. 5a) might even indicate that the enemy could boast about the God of the supplicant having been disempowered. This is in line with the ancient Near Eastern idea that the victory of one people over another implies the defeat of the conquered people's god by the victorious people's god. ${ }^{37}$ The defeated people's god has thus been disempowered. This means that in the mind of the supplicant, should God not come to his rescue, it would mean a loss of honour for God, who would have to enter the realm of death. ${ }^{38}$ Furthermore, the psalmist's opponents would gloat and ridicule him with malicious pleasure, should he fall. These three requests therefore illustrate the deep anxiety and desperate situation of the psalmist whose only hope is to pray to God for new vitality as well as for his care and compassion.

The transition between verses 5 and 6 shows a striking change in mood, genre and description. Verse 6 is characterised by a declaration of trust, praise and a vow to offer thanksgiving to Yahweh. The "I" is emphasised by means of an antithetical waw and a first person personal pronoun. This "I" has now become the subject who trusts in God's "steadfast love," who feels heartfelt joy over God's salvation and who gratefully offers thanksgiving to God for the benevolence that Yahweh has shown him.

This begs the question, however, of what exactly brought about this change in the supplicant-a question that brings us to consider the interpretation of the time perspectives in verse 6 in relation to verses 1-5. Has a priest or cultic prophet delivered an oracle of salvation (on behalf of Yahweh) between verses 5 and $6 ?^{39}$ Has the whole psalm or even verse 6 been written in retrospect, reflecting on a past experience of deep anxiety, suffering and salvation $?^{40}$ Alternatively, has something happened to bring about a change in the mood of the psalmist so that he anticipates, by means of perfectum profeticum ("because He has done good to me"), the positive outcome and praises and thanks Yahweh before any actual salvation has taken place-thus an anticipatory hymn of praise ${ }^{41}$

One possible interpretation is that the psalmist's dire situation has not yet changed but that the change in his mood was brought about by his trust in

36 In the ancient world, sleep was often used as metaphor or euphemism for death.

Cf. Job 3:13; 14:12; Ps 76:6; Jer 51:39, 57, etcetera.

37 Cf. Ps 137.

38 Zenger, Psalmen 1, 98.

39 Cf. Ps 12:6.

40 Cf. Kidner, Psalms 1-72, 77-78.

41 Prinsloo, Lof van my God, 51. 
God's "steadfast love." ${ }^{42}$ Based on this trust, the psalmist considers God's answer to his prayer to be certain. ${ }^{43}$ A different perspective would be to understand the psalm as having been written in retrospect, after the prayer had been heard. ${ }^{44}$ Based on this experienced salvation, the supplicant offers God a vow of praise and thanksgiving and the communion with God is celebrated in the cult.

It is not necessary to choose only one possible interpretation especially in a psalm that is at times characterised by purposeful ambiguity. The two interpretations are probably both valid in our life experiences. Both bear witness to a genuine faith in the God who provides "light" and "vitality" in order to make the "heart" of the believer sing for joy (v. 6). With joy in the heart and a sacrifice of praise on his lips (v. 6), the once daily distressed heart of the sufferer (v. 3) is turned around chiastically. The experience of being deserted by God and of anxiety is replaced by trust and joy (v. 6). A near death experience is replaced by new vitality. Complaint becomes praise through the working of God's steadfast love - that good deed which He offers a person in misery. Yahweh has ultimately turned his 'face' and 'eyes' towards the lifeseeking sufferer for healing and wholeness.

\section{SITZ(E) IM LEBEN AND DATE}

The language and descriptions of the psalmist's experience of fear of death and being abandoned by God is very generally formulated so that it provides no specific historical, semantic or theological indications that would contribute to a (more exact) dating of the psalm. There is also considerable difference regarding the nature of the psalmist's desperate situation. Some scholars argue that he might have been ill, ${ }^{45}$ others that enemies persecuted and oppressed $\operatorname{him}^{46}$ and still others that he became the object of God's wrath due to a debt of unrighteousness. ${ }^{47}$ Since the psalmist's exact historical life setting (Sitz im

42 See Clifford, Psalms 73-150, 88. This "steadfast love" or hesed is the gracious favour that Yahweh offers his people and individuals (Zenger, Psalmen 1, 99). In the context of Ps 13, it indicates the faithfulness of God's loyalty in showing his salvation (Prinsloo, Lof van my God, 51). Cf. Pss 26:3; 136:1-26, etcetera.

43 Fohrer, Psalmen, 147.

44 Arthur Weiser, The Psalms: A Commentary (OTL; London: SCM Press, 1962), 163.

45 Hans Schmidt, Die Psalmen (HAT I/15; Tübingen: Mohr Siebeck, 1934), 22; Weiser, Psalms, 162; John H. Eaton, The Psalms: A Historical and Spiritual Commentary with an Introduction and New Translation (London: T \& T Clark, 2003), 91.

46 Rudolph Kittel, Die Psalmen übersetzt und erklärt (Leipzig: Werner Scholl, 1929), 40.

47 Kraus, Psalmen, 241. 
Leben) cannot be determined, the conclusion that the psalm's dating is destined to remain uncertain seems justified. ${ }^{48}$

Past attempts at dating Ps 13 included (1) a link to David (based on the heading, "Of David") with a pre-exilic dating because David fled for his life before Saul; ${ }^{49}$ (2) early or pre-exilic dates motivated by the similarities with Babylonian laments and prayers ${ }^{50}$ or by the absence of wishes for the destruction of the enemy (when the text is compared with younger psalms) ${ }^{51}$ (3) exilic or post-exilic dates, e.g. that of Duhm, ${ }^{52}$ who argues that conflict and infighting between individuals and groups in the post-exilic community never ceased, so that this period offers a suitable setting for the psalm; (4) a date of the text closer to the catastrophic events of 344 B.C.E. ${ }^{53}$

The general nature of the semantic formulations in the psalm makes dating the text particularly difficult, but at the same time lends the text and the psalmist's experience of suffering a paradigmatic and exemplary character. The fact that distress, deep anxiety over death, and the experience of being deserted by God forms part of the existential experience of humanity makes a pre-exilic date of origin a strong possibility. However, the applicability of the experience to a group or the greater Israelite community is also possible, in which case the text would have become part of a smaller group or a collection of psalms (e.g. Pss 3-14) as part of an "Armentheologie"-redaction, in order to actualise it anew in an exilic period or the post-exilic times of the Persian or Hellenistic eras.

Coming to the cultic context or Sitz im Leben, the text and its allusions

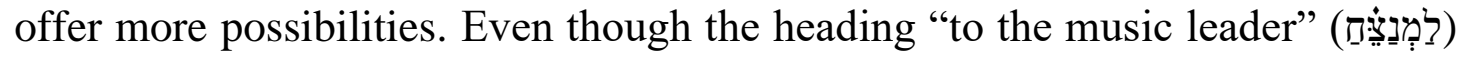
is a later addition to the text, it alludes to a certain cultic use of the psalm. Postexilic Levitical guilds or priests were probably responsible for this. Was it an oracle spoken by a temple prophet ${ }^{54}$ The liturgical acts of prayer (vv. 4-5), singing and praise as a sacrifice of thanksgiving (v. 6) confirm that the psalm

48 The following are some of the scholars who have come to this conclusion: Alfons Deissler, Die Psalmen (Düsseldorf: Patmos Verlag, 1964), 62; Anderson, 1-72, 128; Zenger, Psalmen 1, 96; Prinsloo, Lof van my God, 48; Terrien, Psalms, 161.

49 See Alexander F. Kirkpatrick, The Book of Psalms (Cambridge: University Press, 1957), 63; and Herman N. Ridderbos, De Psalmen: Vertaalt en Verklaard (Kampen: Kok, 1955), 108. Texts mentioned as motivation in this regard include 1 Sam 27:1; $24: 4 ; 26: 8$ and Ps 7:1.

50 Peter C. Craigie, Psalms 1-50 (WBC; Edmonds: Thomas Nelson, 2004), 141. See also Jüngling, International Bible Commentary, 791.

51 Zenger, Psalmen 1, 96.

52 Bernhard Duhm, Die Psalmen (KHC 14; Tübingen: Mohr/Siebeck, 1922), 53.

53 Moses Buttenwieser, The Psalms (Chicago: University of Chicago, 1938), 617.

54 Cf. Cyril Rodd, "Psalms" in The Oxford Bible Commentary (ed. John Barton and John Muddiman; Oxford: Oxford University Press, 2001), 371. 
was applicable in various opportunities for worship in the cult. The calling on God's name and the triad of prayer requests ["behold/look at me" (v. 4), "answer me" (v. 4) and "keep the light in my eyes" (v. 4)] fit in the sanctuary as prayer formulas. ${ }^{55}$ It can therefore be assumed with certainty that the psalm functioned at different periods in the Israelite cult.

\section{CANONICAL GROUPING (PSS 3-14)}

Book I of the Psalter (Pss 1-41) can be subdivided into several smaller collections namely 1-2 (framework and introduction to the Psalter), 3-14, 1524, 25-34 and 35-41. ${ }^{56}$ Each of these sub-divisions reflects its own structure and theological inclination. Based on the heading, "Of David" Pss 3-41 comprise the first of five Davidic collections.

Inside the first Davidic collection (Pss 3-41), the smaller group of Pss 314 consists of two subdivisions namely Pss 3-7 and 11-14, with Ps 8 as the centre text. ${ }^{57}$ Both groups exhibit a linear structure, with Pss 7 and 14 forming the climax of each collection. The first collection (3-7) describes the way of the supplicant to righteousness, while the second (11-14) ponders the question of Yahweh's delayed salvation for the righteous. With the theme of power and lack of power of humanity, Ps 8 serves as a hinge and hermeneutical key for the theological understanding of the collection 3-7.8.11-14. ${ }^{58}$ In a later time (Hellenistic period), Ps 9/10 might have constituted a second centre for the extended collection (Pss 3-14), not as replacement of Ps 8, but as complementary interpretative climax..$^{59}$

55 Fohrer, Psalmen, 144; Prinsloo, Lof van my God, 49.

56 Cf. Frank-Lothar Hossfeld and Erich Zenger, Die Psalmen I: Psalm 1-50 (Neue Echter Bibel 29; Würzburg: Echter Verlag, 1993), 12; Erich Zenger, "Der Psalter als Buch. Beobachtungen zu seiner Entstehung, Komposition und Funktion," in Der Psalter in Judentum und Christentum (ed. Erich Zenger; Freiburg: Herder Verlag, 1998), 19-22.

57 Hartenstein, "Schaffe mir Recht, JHWH," 253-254, is of the opinion that this basic composition dates from the earliest exilic times. In Hellenistic times, Pss 9 (hymn of thanksgiving) and 10 (lament and prayer) were added as the new centre to the psalms, bringing about a new actualisation of the meaning of the collection. This new centre forms a second hinge and does not replace the original function of the psalm. See Zenger, "Einführung," 10.

58 Zenger, "Einführung," 10. See also how Zenger, Psalter in Judentum, 19-20, analyses this group of psalms (Pss 3-14); see similarly the exposition of Philip Sumpter, "Canonical Shape of Psalms 1-14," Old Testament Essays 32/2 (2019): 514543.

59 Cf. the thorough literary motif and genre analysis of Gianni Barbiero, Das erste Psalmbuch als Einheit: Eine synkrone Analyse von Psalm 1-41 (Österreichische Biblische Studien 16; Frankfurt am Main: Lang, 1999), 63-187. 
Close relationships seem evident between Ps 13 and Pss 3-7, although there are clear links with and even climactic emphasis of theological accents with Pss $11-12$ and $14 .{ }^{60}$ Thematic and terminological resemblances similarly occur between Ps 13 and Pss 9/10-12. ${ }^{61}$ The descriptions of the enemy and the theme of God-forsakenness in Ps 13 appear, particularly, in Ps 3-7 with a strong affinity between Ps 13 and Ps $6 .^{62}$

With the themes of God-forsakenness and intense anxiety in the face of death, Ps 13 offers, in the larger context, a principle by which to explain the delayed salvation of the righteous. How long will salvation be held back in light of God forgetting and "turning" his "face away" (v. 2)? Will God respond positively to the request to shine the face of his countenance $(4: 7=13: 4)$ ? The additional question is who will eventually rejoice? Whose situation will change - the enemy and opponents (13:5) or the supplicant? The answer of Ps 13:6 finds resonance in 14:7-Yahweh's act of salvation brings both the supplicant and the people of Israel to joyful celebration.

Theological inclinations in Pss 3-14 find, in Ps 13, an intensified theological core. In this way, the redactional placement of Ps 13 in the greater context of this collection gives this psalm a key hermeneutic role to explain the theological programme of the redaction, with both the individual Yahweh believer ('I') and collective Israel at the heart of this experience.

\section{E SYNTHESIS}

As a typical lament of the individual, Ps 13 describes a righteous supplicant's experience of desolation and abandonment by God. This psalmist experiences intense anxiety in the face of death. In an intense encounter, the supplicant confronts God and bemoans his fate in a prayer of conflict. Following his fourfold complaint, he makes three requests to his God for new vitality. At the precipice of death, he asks that God looks on and answers him; that God gives light to his eyes and grants him victory over his enemy so that the malicious pleasure of his opponents will come to nothing. In a sudden shift of events, the supplicant confesses his trust in Yahweh's "steadfast love," which is the very reason for his praise of God for the benevolence ultimately shown to him.

Psalm 13 describes a basic life experience of a Yahweh-believer-how to move from complaint to praise. This prayer of conflict illustrates the

60 Zenger, Psalmen 1, 93 and Beat Weber, Die Psalmen 1 bis 72 (Vol. 1 of Werkbuch Psalmen; Stuttgart: Kohlhammer, 2001), 88 describe the similarities of keywords and of the rising climax that exist as a theological programme in Pss 12-14.

61 Cf. Hans-Winfried Jüngling, The International Bible Commentary, 790, who illustrates these resemblances - actions of the godless, descriptions of enemies, plea to God not to forget, God's rising up, confidence in God, salvation.

62 Hartenstein, "Schaffe mir Recht, JHWH," 252. 
psalmist's trust in God despite his complaints. This conflict encounter transforms his experiences of desolation, abandonment and anxiety into the joy of renewed communion with his God. God is both involved in suffering but also in the response to suffering namely salvation. ${ }^{63}$ Psalm 13 underscores the theological perspective that human suffering is therefore in need of God's 'face' and 'eyes' for such a transformation. By lamenting to God in near death crises, the supplicant reaches the joy of life again - a fitting paradigm for humanity and for Africa and her people who experience such suffering and great humanitarian challenges. ${ }^{64}$

\section{H BIBLIOGRAPHY}

Adeyemo, Tokunboh, ed. Africa Bible Commentary. Grand Rapids: Zondervan, 2006.

Anderson, Arnold A. Psalm 1-72. Vol. 1 of The Book of Psalms. NCBC. Grand Rapids: Wm. B. Eerdmans, 1972.

Barber, Sharrelle. "Death by Racism. Racial Violence and Racial Health Inequities in the Midst of the COVID-19 Pandemic Disproportionately Impact on Blacks." The Lancet Aug 20 (2020): 903.

Barbiero, Gianni. Das erste Psalmbuch als Einheit. Eine synkrone Analyse von Psalm 1-41. Österreichische Biblische Studien 16. Frankfurt am Main: Lang, 1999.

Bentzen, Aage. King and Messiah. Oxford: Blackwell, 1955.

Buttenwieser, Moses. The Psalms. Chicago: University of Chicago, 1938.

Clifford, Richard J. Psalms 73-150. Abingdon Old Testament Commentaries. Nashville: Abingdon Press, 2003.

Craigie, Peter C. Psalms 1- 50. WBC. Edmonds: Thomas Nelson, 2004.

Daniels, Princilla and Tracey-Ann Adonis. "Domestic Violence in South Africa: Problems and Prospects." Pages 151-164 in Global Responses to Domestic Violence. Edited by E.S. Buzawa and C.G. Buzawa. New York: Springer Publishing, 2017.

DeClaissé-Walford, Nancy, Rolf A. Jacobson and Beth L. Tanner. The Book of Psalms. NICOT. Grand Rapids: Eerdmans, 2014.

Deissler, Alfons. Die Psalmen. Düsseldorf: Patmos Verlag, 1964.

Duhm, Bernhard. Kurzer Handkommentar zum Alten Testament: Die Psalmen. Freiburg: Mohr (Siebeck), 1922.

Dunn, James D.G. and John W. Rogerson, eds. Eerdmans Commentary on the Bible. Grand Rapids: Wm. B. Eerdmans, 2003.

Eaton, John H. Psalms: A Historical and Spiritual Commentary with an Introduction and New Translation. London: T \& T Clark, 2003.

Fohrer, Georg. Psalmen. Berlin/New York: Walter de Gruyter, 1993.

Gerstenberger, Erhard S. Psalms Part 1. With an Introduction to Cultic Poetry. FOTL 14. Grand Rapids: Eerdmans, 1988.

Gressmann, Hugo et al. Altorientalische Texte zum alten Testament. Altorientalische Texte und Bilder zum Alten Testament. Berlin: Walter de Gruyter, 1926.

63 Jacobson, Book of Psalms, 163.

64 Cf. Tokunboh Adeyemo, ed. Africa Bible Commentary (Grand Rapids.: Zondervan, 2006), 1347-1349. 
Gunkel, Hermann. Die Psalmen. 4th ed. HAT 2/2. Göttingen: Vandenhoeck \& Ruprecht, 1926.

Hallo, William W. and K. Lawson Younger. The Context of Scripture: Canonical Compositions from the Biblical World. Vol.1. Leiden: Brill, 1997.

Hartenstein, Friedhelm. Das Angesicht JHWHs. FAT 55. Tübingen: Mohr Siebeck, 2008.

"'Schaffe mir Recht, JHWH' (Psalm 7,9): Zum theologischen und anthropologischen Profil der Teilkomposition Psalm 3-14." Pages 229-258 in The Composition of the Book of Psalms. Edited by Erich Zenger. BETL. Leuven: Peeters, 2010.

Hossfeld, Frank-Lothar and Erich Zenger. Die Psalmen I: Psalm 1-50. Neue Echter Bibel 29. Würzburg: Echter Verlag, 1993.

Jacobson, Rolf A. "Psalm 13: Waiting on the Lord." Pages 158-163 in The Book of Psalms. Edited by Nancy DeClaissé-Walford, Rolf A. Jacobson and Beth L. Tanner. NICOT. Grand Rapids: Eerdmans, 2014.

Janowski, Bernd. "Ein Tempel aus Worten: Zur theologischen Architektur des Psalters." Pages 279-306 in The Composition of the Book of Psalms. Edited by Erich Zenger. BETL. Leuven: Peeters, 2010. . Konfliktgespräche mit Gott: Eine Antropologie der Psalmen. Neukirchen: Neukirchener Verlag, 2013.

. Anthropologie des Alten Testaments: Grundfragen - Kontexte Themenfelder. Tübingen: Mohr Siebeck, 2019.

Jüngling, Hans-Winfried. "Psalms 1-41." Pages 779-822 in The International Bible Commentary. Edited by William R. Farmer. Collegeville: The Liturgical Press, 1998.

Kidner, Derek. Psalms 1-72. Tyndale Old Testament Commentaries. London: Intervarsity Press, 1973.

Kirkpatrick, Alexander F. The Book of Psalms. Cambridge: University Press, 1957.

Kittel, Rudolph. Die Psalmen übersetzt und erklärt. Leipzig: Werner Scholl, 1929.

Kraus, Hans-Joachim. Biblischer Kommentar Altes Testament XV/1: Psalmen 1-59. Neukirchen: Neukirchener Verlag, 1978.

Kruger, Ferdinand P. and Ben J. De Klerk. Corruption in South Africa's Liberal Democratic Context: Equipping Christian Leaders and Communities for Their Role in Countering Corruption. Cape Town: AOSIS, 2016.

Mays, James L. Psalms. Interpretation. Louisville: John Knox, 1994.

McKibbin Warwick and Roshen Fernando. "The Economic Impact of COVID-19." Pages 45-51 in Economics in the Time of COVID-19. Edited by Richard Baldwin and Beatrice Weder di Mauro. London: CEPR Press, 2020.

Mowinckel, Sigmund. The Psalms in Israel's Worship. Vol. 1. Oxford: Blackwell, 1967.

Panu, Pihkalu. "Anxiety and the Ecological Crisis: An Analysis of Eco-Anxiety and Climate Anxiety." Sustainability 12/19 (2020): 7836, 120; https://doi.org/10.3390/su12197836.

Prinsloo, Willem S. Die lof van my God solank ek lewe. Centurion: Medpharm, 2000. . "Psalms." Pages 364-436 in Eerdmans Commentary on the Bible. Edited by James D.G. Dunn and John W. Rogerson. Grand Rapids: Wm. B. Eerdmans, 2003 . 
Pritchard, James B. Ancient Near Eastern Texts Relating to the Old Testament. Princeton: Princeton University Press, 1969.

Ridderbos, Hermann N. De Psalmen: Vertaalt en Verklaard. Kampen: Kok, 1955.

Rodd, Cyril S. "Psalms." Pages 355-405 in The Oxford Bible Commentary. Edited by John Barton and John Muddiman. Oxford: Oxford University Press, 2001.

Salahuddin, Muhammad, Nick Vink, Nicholas Ralph and Jeff Gow. "Globalisation, Poverty and Corruption: Retarding Progress in South Africa." Development $\begin{array}{llll}\text { Southern } & \text { Africa } & 37 & \text { (2020): }\end{array}$ https://doi.org/10.1080/0376835X.2019.1678460.

Schmidt, Hans. Die Psalmen. Handbuch zum Alten Testament I/15. Tübingen: Mohr (Siebeck), 1934.

Seybold, Klaus. Die Psalmen. Handbuch zum Alten Testament I/15. Tübingen: Mohr (Siebeck), 1996.

Sumpter, Philip. "Canonical Shape of Psalms 1-14." Old Testament Essays 32/2 (2019): 514-543.

Terrien, Samuel. The Psalms: Strophic Structure and Theological Commentary. Grand Rapids: Eerdmans, 2003.

Van der Ploeg, Jean P.M. Psalmen deel II: Psalm 1-75. Roermond: J. J. Romen \& Zonen-Uitgevers, 1971.

Vorster, Jacobus M. "Managing Corruption in South Africa: The Ethical Responsibility of Churches." Scriptura 109 (2012): 133-147.

Weber, Beat. Werkbuch Psalmen I: Die Psalmen 1 bis 72. Stuttgart: Verlag W. Kohlhammer, 2001.

Weiser, Arthur. The Psalms: A Commentary. London: SCM Press, 1962.

Westermann, Claus. The Living Psalms. Translated by J. R. Porter. Edinburgh: T \& T Clark, 1989.

Zenger, Erich. "Psalm 13" in Psalmen 1-50. Part 1 of Die Psalmen. Herausgegeben von Erich Zenger and Frank-Lothar Hossfeld. Neue Echter Bibel. Würzburg: Echter Verlag, 1993.

. "Der Psalter als Buch. Beobachtungen zu seiner Entstehung, Komposition und Funktion." Pages 1-58 in Der Psalter in Judentum und Christentum. Edited by Erich Zenger. Freiburg: Herder Verlag, 1998.

. Hrsg. The Composition of the Book of Psalms. BETL. Leuven: Peeters, 2010. . "Einführung." Pages 1-14 in The Composition of the Book of Psalms. Edited by Erich Zenger. BETL, Leuven: Peeters, 2010.

Dirk Human is Professor in Old Testament Studies in the Department of Old Testament and Hebrew Scriptures, Faculty of Theology and Religion, University of Pretoria. Email: dirk.human@up.ac.za. ORCID ID: https://orcid.org/0000-0003-0346-4209. 